\title{
Comparative evaluation of extraction methods for apoplastic proteins from maize leaves
}

Katja Witzel ${ }^{1,3}$, Muhammad Shahzad ${ }^{1}$, Andrea Matros², Hans-Peter Mock ${ }^{2}$ and Karl H Mühling ${ }^{1 *}$

\begin{abstract}
Proteins in the plant apoplast are essential for many physiological processes. We have analysed and compared six different infiltration solutions for proteins contained in the apoplast to recognize the most suitable method for leaves and to establish proteome maps for each extraction. The efficiency of protocols was evaluated by comparing the protein patterns resolved by 1-DE and 2-DE, and revealed distinct characteristics for each infiltration solution. Nano-LC-ESI-Q-TOF MS analysis of all fractions was applied to cover all proteins differentially extracted by infiltration solutions and led to the identification of 328 proteins in total in apoplast preparations. The predicted subcellular protein localisation distinguished the examined infiltration solutions in those with high or low amounts of intracellular protein contaminations, and with high or low quantities of secreted proteins. All tested infiltration solution extracted different subsets of proteins, and those implications on apoplast-specific studies are discussed.
\end{abstract}

Keywords: Apoplast, liquid chromatography mass spectrometry, maize, proteome analysis, two-dimensional gel electrophoresis

\section{Background}

The plant apoplast comprises the cell wall matrix and the intercellular spaces, and plays a major role in a wide range of physiological processes, including water and nutrient transport [1], plant-pathogen interactions, and perception and transduction of environmental signals $[2,3]$. Proteins present in the plant apoplast reflect this broad functional diversity. Studies on the dynamic change of apoplast protein composition revealed new insights into plant responses to abiotic stress [4-7], nutrient supply [8-10], wounding [11], water deficiency $[12,13]$, pathogen response [14-16] and xylem composition $[17,18]$. The selection of a suitable extraction proto$\mathrm{col}$ is a crucial step in proteomics surveys as proteins reveal a high degree of biochemical heterogeneity and investigated plant materials can be characterized by the presence of non-protein components interfering with subsequent analytical techniques, e.g. two-dimensional gel electrophoresis (2-DE) or liquid chromatographymass spectrometry (LC-MS). These biological realities led to the establishment of sample preparation methods

\footnotetext{
* Correspondence: khmuehling@plantnutrition.uni-kiel.de 'Institute of Plant Nutrition and Soil Science, Christian Albrechts University, Hermann-Rodewald-Strasse 2, 24118 Kiel, Germany

Full list of author information is available at the end of the article
}

for numerous plant species and tissues, such as Arabidopsis leaves [19], papaya leaves [20], sunflower leaves [21], cotton seedlings [22], apple and strawberry fruit [23], potato tuber [24], grapevine leaves and roots [25], grape berry cell wall [26], rubber latex [27], cotton fibers [28], banana meristem [29] and chloroplast [30], among others. Despite their biological significance, investigations on apoplastic proteins are hampered due to their low abundance compared to intracellular protein concentrations. The extraction of proteins from the leaf and root apoplast is mainly based on the principle of vacuum infiltration with an extraction solution, followed by a mild centrifugation step to collect the apoplastic washing fluid. The composition of the infiltration solution is essential as it has to fulfil certain prerequisites, such as maintenance of osmotic pressure to prevent collapsing of plasma membrane and stringency for extracting cell wall-bound proteins. Borderies et al. [31] compared different solutions to extract loosely bound cell wall proteins of Arabidopsis cell suspension cultures and showed that the composition of extraction solution determines the efficiency of preparation. Similarly, Boudart et al. [32] investigated weakly cell wall-bound proteins in rosettes of Arabidopsis. Here, we compared protein extracts obtained by six different infiltration
C Biomed Central 
solutions already described for apoplastic proteins from different plant species. We aimed at identifying a protocol most suitable for the extraction of leaf apoplast proteins of maize, a crop of high economic importance. We evaluated the protein patterns as resolved by 1 -DE or 2DE, identified the proteins using LC-MS and located them to cellular compartments.

\section{Results and discussion}

In this study, six different solutions were tested for the ability to extract proteins from the maize leaf apoplast: water [8], $20 \mathrm{mM}$ ascorbic acid/20 $\mathrm{mM} \mathrm{CaCl} 2$ [6], 100 $\mathrm{mM}$ sorbitol [4], $25 \mathrm{mM}$ Tris- $\mathrm{HCl}$ [9], $100 \mathrm{mM}$ sodium phosphate buffer [16] and $50 \mathrm{mM} \mathrm{NaCl}$ [33] (Figure 1). In most cases, the infiltration solutions were applied for wheat leaves and no comparison of the efficiency of protein extraction for each method was performed. Thus, this study focussed on identifying the optimal method for extracting apoplastic proteins from maize leaves.

Proteins from the leaf apoplast and symplast extracted with the six infiltration solutions were compared on 1DE (Figure 2A, Additional file 1). A sharp band pattern was obtained from all apoplast extracts with a high number of protein bands in each extract. While the yield of protein extraction was similar, the protein profiles showed distinct differences. A prominent band of about $20 \mathrm{kDa}$ was present in extracts of $100 \mathrm{mM}$ sodium phosphate buffer, $25 \mathrm{mM}$ Tris- $\mathrm{HCl}, 20 \mathrm{mM}$ ascorbic acid/20 $\mathrm{mM} \mathrm{CaCl}$ and $50 \mathrm{mM} \mathrm{NaCl}$, but not in water or $100 \mathrm{mM}$ sorbitol. One protein band of high molecular weight (approximately 100-130 kDa) was apparent in extracts of water, $100 \mathrm{mM}$ sodium phosphate buffer and $100 \mathrm{mM}$ sorbitol, but not in $25 \mathrm{mM}$ Tris- $\mathrm{HCl}, 20 \mathrm{mM}$ ascorbic acid/20 $\mathrm{mM} \mathrm{CaCl} 2$ or 50 $\mathrm{mM} \mathrm{NaCl}$. While there were similarities, each extract revealed specific protein bands indicating that different subsets of proteins were isolated by the six infiltration solutions. Proteins with a molecular weight $<15 \mathrm{kDa}$ were underrepresented in all extracts and this corresponds to previous proteomic reports on some of the infiltration solutions $[4,16]$. The observed selective protein patterns generated by the individual infiltration solutions emphasize the necessity of careful selection of isolation method [34]. Band patterns from symplast preparations did not reveal significant differences among the infiltrates and the overall band patterns were more complex as from apoplastic preparations. This demonstrates an apparent subfractionation of the cellular compartments.

Equal amounts of apoplast proteins were separated by 2$\mathrm{DE}$ to assess the protein patterns in more detail (Figure 2B). We found areas of good and poor resolved proteins

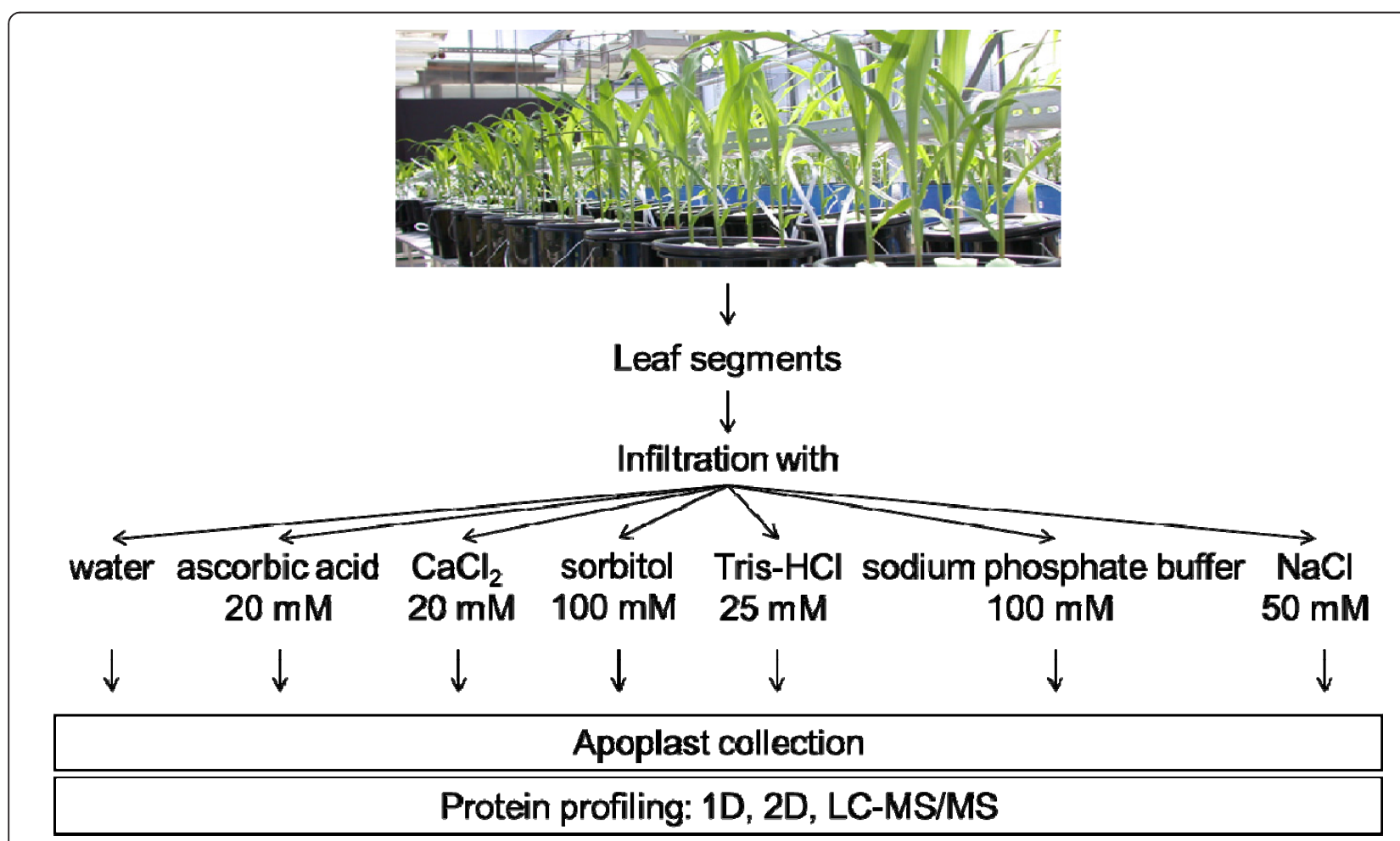

Figure 1 Schematic representation of protein extraction from maize leaf apoplast. Different infiltration solutions were analyzed for their specificity by proteome profiling using gel-based and gel-free approaches. 


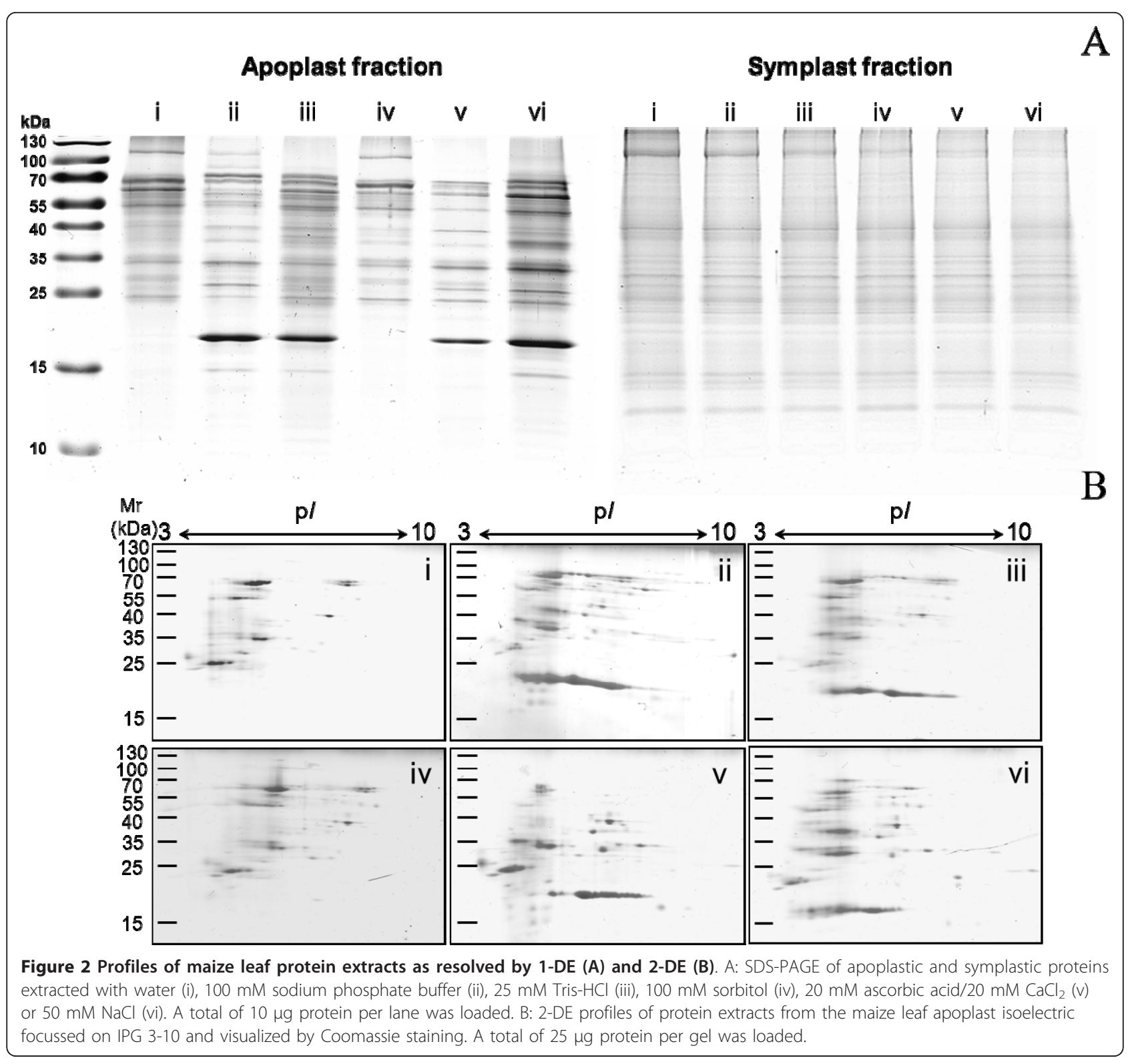

spots on all 2-D gels. Proteins in the acidic gel region of pH 4-6 showed horizontal streaking. Although all samples were precipitated, dissolved in urea-containing buffer system and dialyzed prior to 2-DE to avoid the contamination with nucleic acids or other interfering substances, these poorly separated spots were observed. Contrary to this, proteins in the basic region of 2-D gels near the $\mathrm{pH}$ 6-10 interval showed a superior resolution with minimal streaking. The spot patterns resembled the band patterns to a certain extent, e.g. as observed for the $20 \mathrm{kDa}$ band that was prominent also on 2-D gels of the respective apoplastic extracts. The best resolution of proteins in $25-45 \mathrm{kDa}$ intervals was achieved on extracts of $20 \mathrm{mM}$ ascorbic acid/20 $\mathrm{mM} \mathrm{CaCl} \mathrm{Cl}_{2}$ infiltration solution, while high molecular weight proteins separated best in extracts of $100 \mathrm{mM}$ sodium phosphate buffer infiltration solution. The latter was applied with success to extract proteins from the leaf apoplast of lupin and resulted in the generation of well resolved protein maps containing about 50 spots to evaluate the effect of water and boron deficiency [9]. Our results showed that this separation was not reached, probably due to substances present in the maize apoplast interfering with isoelectric focusing. As 2-DE did not result in a comprehensible evaluation of the employed infiltration solutions, we used nano-LC-ESI-Q-TOF MS for proteomic analysis of all extracts.

In order to obtain an overview of all proteins present in the six different extracts, we aimed at establishing 
qualitative protein profiles by LC-MS analysis. An automatic data directed analysis mode was applied as described in materials and methods section. Results exceeding the PLGS score of 12 for protein identification and probability score of $50 \%$ for de novo sequencing of peptides were accepted.

A total of 328 proteins were identified from all extracts. Additional file 2 shows the identities of those proteins, along with the predicted subcellular localization and detection in the six apoplastic extracts. Additional file 3 provides the respective identifier, PLGS score, number of peptides, protein coverage, peptide sequences and peptide sequence probability score for all identified proteins. In order to visualize and identify infiltration solutions with similar protein abundance patterns, a hierarchical clustering method was applied. Two main clusters were found, with the first represented by the $100 \mathrm{mM}$ sodium phosphate buffer and the second containing all other infiltration solutions indicating the isolation of a rather different set of proteins by the first one than compared to all other solutions under examination (Figure 3). The most similar abundance patterns derived from leaf infiltration with $25 \mathrm{mM}$ Tris- $\mathrm{HCl}$ and $50 \mathrm{mM} \mathrm{NaCl}$ reflecting a comparable degree of protein extraction efficiency.

The highest number of proteins was found in apoplastic extracts using water as infiltration solution. Here, 171 proteins were detected. Extracts of $25 \mathrm{mM}$ Tris- $\mathrm{HCl}$, $100 \mathrm{mM}$ sorbitol and $20 \mathrm{mM}$ ascorbic acid/20 mM $\mathrm{CaCl}_{2}$ yielded in the identification of a similar number of 131,133 and 133 proteins, respectively. We found 114 proteins in extracts of $50 \mathrm{mM} \mathrm{NaCl}$ solution and 107 proteins in those of $100 \mathrm{mM}$ sodium phosphate buffer. Out of all 328 proteins, only 28 proteins were common across all six extracts (Additional file 4). A similar observation was made for Arabidopsis cell wall proteins when extracted by different solutions; here, only 11 out of 96 proteins were found to be common in all extracts [31]. Exhydrolase II [UniProt: Q9XE93] was found in all extracts and its identification is illustrated in Additional file 5 as an example. Here, the amino acid sequence is shown and the 12 detected peptides are marked within, resulting in protein sequence coverage of $28.7 \%$.

The quality of apoplastic protein preparations is estimated in many cases by enzymatic measurements of specific proteins such as malate dehydrogenase [5,9] and glucose-6-phosphate dehydrogenase [6]. However, it is known that the activity of those enzymes is detectable in respective cellular compartment as well [35]. To assess the amount of symplast contaminations in our samples, we used topology prediction tools. The identified proteins were classified for their subcellular localization as deduced by Expasy tools Target P and WoLF
PSORT (Figure 4). A number of proteins in this study were allocated to other cellular compartments then the apoplast, suggesting considerable amounts of intracellular protein contaminations. However, previous reports using different plant species and extraction methods described the detection of cytosolic, mitochondrial or vacuolar proteins in cell wall or apoplast preparations [31,36-38]. These consistent findings point to the occurrence of non-classical secretory pathways for proteins lacking signal sequences $[39,40]$ and therefore, differentiation between yet unknown apoplastic proteins and ones resident in other organelles remains difficult. Water-infiltrated leaves revealed 23 protein identifications localized to the apoplast, while a high number of intracellular proteins were detected from the vacuole (19), cytosol (46) and chloroplast (23). This observation is indicative for the disrupture of plasma membrane during the infiltration process. Also, apoplastic extracts with $100 \mathrm{mM}$ sorbitol as infiltration solution contained a superior proportion of chloroplast (26) and cytosolic (41) proteins with only 15 predicted apoplastic proteins. This result was unexpected as the sugar alcohol sorbitol was applied to maintain the osmotic cell pressure. Similar numbers of proteins in infiltrates with $25 \mathrm{mM}$ Tris$\mathrm{HCl}, 20 \mathrm{mM}$ ascorbic acid/20 $\mathrm{mM} \mathrm{CaCl}_{2}$ and $50 \mathrm{mM}$ $\mathrm{NaCl}$ were assigned to the chloroplast $(14,17,14)$, the cytosol $(36,34,27)$, and the apoplast $(25,31,25)$. Of all tested infiltration solutions, $100 \mathrm{mM}$ sodium phosphate buffer contained the lowest number of proteins assigned to intracellular compartments (chloroplast: 10, cytosol: 16) and the highest number of proteins targeted to the extracellular apoplast with 34 identified proteins.

Table 1 presents the 67 proteins allocated to the apoplast of maize leaves and grouped according to their function into 7 classes. The largest class consisted of 39 proteins related to cell structural processes, including carbohydrate metabolism (e.g.: lichenase 2, alpha N-arabinofuranosidase, beta galactosidase, exoglucanase, exhydrolase II) and cell wall modification (e.g.; pectinesterase, xyloglucan endotransglycosylase hydrolase, peroxidases). Synthesis and integration of polysaccharides into the cell wall and extension of this network during plant growth are the major biological functions of proteins present in the apoplast [41] and our findings reflect this reality. Fifteen proteins were involved in disease and defense reactions, the second prime function of the apoplast [42]. The third class was related to proteins with transporting function and here, 7 proteins were identified. Further classes were related to cell growth/division, protein destination/storage, secondary metabolism and signal transduction.

The number of proteins identified exclusively in any of the extracts was compared and revealed that 16 out of 34 apoplastic proteins were found only in extracts of 


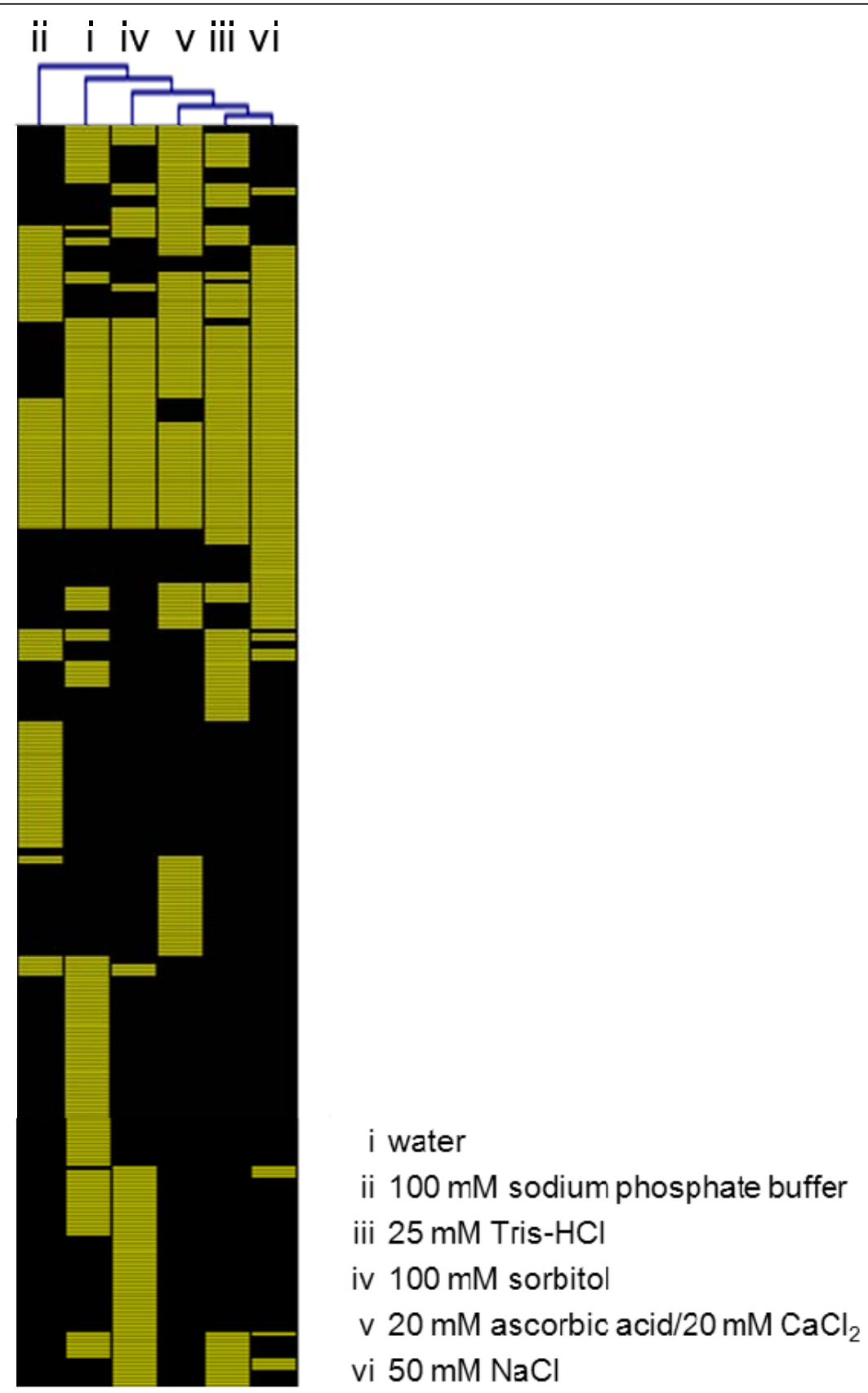

Figure 3 Hierarchical clustering analysis of protein abundance patterns. Columns represent LC-MS experiments on protein extracts of indicated infiltration solutions. Rows display the presence (yellow) or absence (black) of proteins in the respective extracts. Additional file 2 provides protein identifications and their detection in the respective apoplast extracts.

$100 \mathrm{mM}$ sodium phosphate buffer, representing the highest number of unique proteins in all tested infiltration solutions (Table 1). Usage of this infiltration solution appears to prevent damaging the plasma membrane and enables extraction of proteins adhesive to the cell wall. Most polypeptides found in the analysis were annotated as hypothetical based on an in silico match to a genome sequence, or putative due to a homology to a protein with known function (Figure 4). The identification of these proteins in apoplastic preparations reveals the potential inherited in proteomic surveys for establishing comprehensive maps of all translated polypeptides present in a subcellular compartment. A number of 12 proteins with unknown function were exclusively identified using the $100 \mathrm{mM}$ sodium phosphate buffer infiltration solution (see Additional file 2). As this 


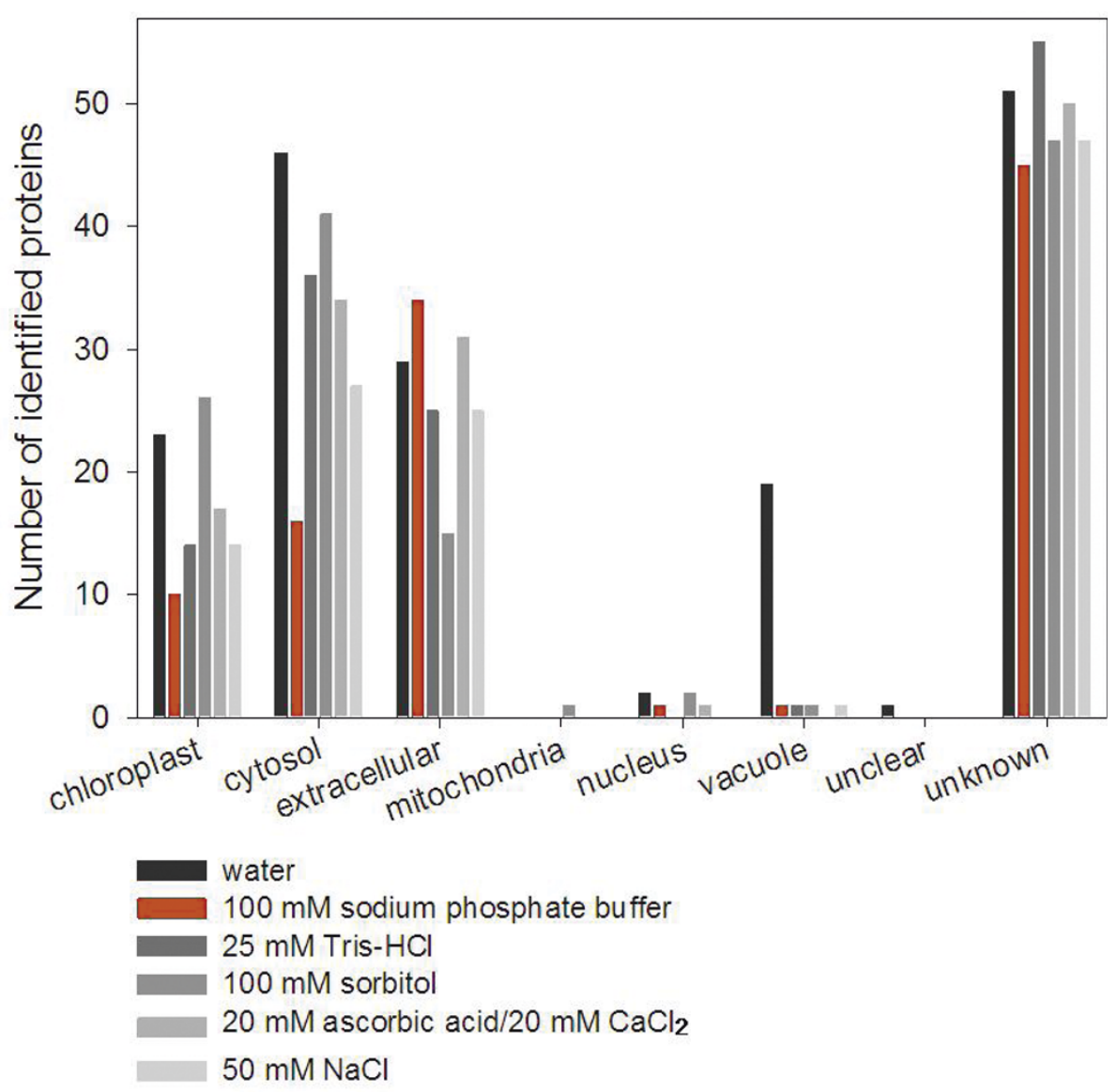

Figure 4 Predicted subcellular distribution of identified proteins from the maize leaf apoplast extracted by different infiltration solutions. Topology prediction was performed with Expasy tools Target P (http://www.cbs.dtu.dk/services/TargetP/) and WoLF PSORT (http:// wolfpsort.org/).

protein fraction performed best regarding contaminations from other cellular compartments and contained most of the apoplastic proteins, we assume that these yet unknown proteins are involved in physiological processes of the apoplast.

\section{Conclusions}

The plant apoplast is a dynamic compartment with a broad range of physiological functions. To study proteins involved in nutrition, growth, signaling or transport processes, it is crucial to apply extraction methods selective for apoplastic proteins. In this study, we compared six different infiltration solutions already reported for the isolation of this protein subset. The protein patterns resolved by 1-DE revealed clear differences between apoplast and symplast preparations. We found the lowest number of intracellular protein contaminants with the highest number of extracted proteins present in the apoplastic fluid obtained with $100 \mathrm{mM}$ sodium phosphate buffer. Also, the number of secreted proteins exclusively found in a single fraction was highest for that buffer. Those findings are now employed in comparative proteomic studies aiming at identifying proteins involved in abiotic stress responses.

\section{Materials and methods Plant cultivation}

Maize grains cv. Lector (LG Seeds, http://www.lgseeds. com) were imbibed overnight in aerated $1 \mathrm{mM} \mathrm{CaSO}_{4}$ solution and germinated at $28^{\circ} \mathrm{C}$ in the dark between two layers of filter paper moistened with $0.5 \mathrm{mM}$ $\mathrm{CaSO}_{4}$. After 4 days, seedlings were transferred to light in constantly aerated plastic pots containing one-fourth concentrated nutrient solution. The concentration of nutrient solution was increased to half and full strength after 2 and 4 days of cultivation, respectively. The full strength nutrient solution had the following concentrations: $2.0 \mathrm{mM} \mathrm{Ca}\left(\mathrm{NO}_{3}\right)_{2}, 1.0 \mathrm{mM} \mathrm{K} \mathrm{SO}_{4}, 0.2 \mathrm{mM}$ $\mathrm{KH}_{2} \mathrm{PO}_{4}, 0.5 \mathrm{mM} \mathrm{MgSO}$, $2.0 \mathrm{mM} \mathrm{CaCl} 2,5.0 \mu \mathrm{M}$ $\mathrm{H}_{3} \mathrm{BO}_{3}, 2.0 \mu \mathrm{M} \mathrm{MnSO}_{4}, 0.5 \mu \mathrm{M} \mathrm{ZnSO}_{4}, 0.3 \mu \mathrm{M} \mathrm{CuSO}_{4}$, 
Table 1 Identification of proteins assigned to the apoplast.

\begin{tabular}{|c|c|c|c|c|c|c|c|c|c|}
\hline \multirow[b]{2}{*}{ Entry } & \multirow[b]{2}{*}{ Description } & \multirow[b]{2}{*}{$\mathrm{mW}(\mathrm{Da})$} & \multirow[b]{2}{*}{$\mathrm{pl}(\mathrm{pH})$} & \multicolumn{6}{|c|}{ Infiltration solutions } \\
\hline & & & & $\bar{i}$ & ii & iii & iv & $\mathbf{v}$ & vi \\
\hline \multicolumn{10}{|c|}{ Cell growth and division } \\
\hline UniRef90_Q6ZDE3 & Abscisic acid 8'-hydroxylase 2, Oryza sativa & 56519 & 9.83 & $x$ & & & & & \\
\hline \multicolumn{10}{|l|}{ Cell structure } \\
\hline 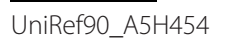 & Peroxidase 66 , Zea maize & 33398 & 8.02 & & & & & $x$ & \\
\hline UniRef90_A5H8G4 & Peroxidase 1, Zea maize & 38330 & 6.89 & & & & & $x$ & \\
\hline UniRef90_A5JTQ2 & Alpha N arabinofuranosidase, Medicago varia & 83673 & 6.22 & & $x$ & & & & \\
\hline UniRef90_B4FKV6 & Peroxidase 54, Zea maize & 36178 & 4.95 & & & & & & $x$ \\
\hline UniRef90_B5AK47 & Dhurrinase-like B glucosidase, Zea maize & 64233 & 7.95 & & & $x$ & & & \\
\hline UniRef90_B6SMR2 & Peroxidase 52, Zea mays & 33504 & 8.14 & & $x$ & $x$ & & $x$ & $x$ \\
\hline UniRef90_B6SUH6 & Non-cyanogenic beta glucosidase, Zea mays & 56680 & 5.39 & $x$ & & $x$ & & $x$ & \\
\hline UniRef90_B6SXU7 & Heparanase-like protein 3, Zea maize & 58262 & 9.35 & $x$ & & $x$ & $x$ & $x$ & $x$ \\
\hline UniRef90_B6SXY3 & Beta galactosidase, Zea mays & 48728 & 8.38 & & $x$ & & & & \\
\hline UniRef90_B6T391 & Lichenase 2, Zea mays & 34951 & 5.64 & $x$ & $x$ & $x$ & $x$ & $x$ & $x$ \\
\hline UniRef90_B6T9B9 & Alpha $\mathrm{N}$ arabinofuranosidase, Zea mays & 74827 & 5.04 & & & $x$ & & $x$ & $x$ \\
\hline UniRef90_B6TU39 & Peroxidase 2, Zea maize & 34941 & 4.67 & & $x$ & & & & \\
\hline UniRef90_B6TU78 & Glucan endo-1-3 beta glucosidase 7, Zea maize & 45316 & 5.54 & $x$ & & & & & \\
\hline UniRef90_B6TXJ8 & Glycoside hydrolase family 28 , Zea maize & 47066 & 5.58 & $x$ & & & & & \\
\hline UniRef90_B6U063 & Carboxylic ester hydrolase, Zea mays & 50032 & 7.85 & $x$ & & $x$ & & $x$ & \\
\hline UniRef90_B6U0W2 & Beta galactosidase, Zea maize & 93935 & 6.48 & & $x$ & & & & \\
\hline UniRef90_B9SD68 & Hydrolase, Ricinus communis & 67825 & 6.80 & $x$ & $x$ & $x$ & & & \\
\hline UniRef90_C4N559 & Xyloglucan endotransglycosylase hydrolase, Musa acuminata & 20309 & 9.54 & & & & & & $x$ \\
\hline UniRef90_C5WQU7 & Beta galactosidase, Sorghum bicolor & 92893 & 5.31 & $x$ & & $x$ & $x$ & $x$ & $x$ \\
\hline UniRef90_C5Z534 & Beta galactosidase, Sorghum bicolor & 79098 & 7.74 & & $x$ & & & & \\
\hline UniRef90_004943 & Alpha galactosidase, Hordeum vulgare & 17730 & 6.33 & & $x$ & $x$ & & $x$ & $x$ \\
\hline UniRef90_P93518 & PRm 3, Zea maize & 30099 & 3.90 & $x$ & $x$ & $x$ & $x$ & $x$ & $x$ \\
\hline UniRef90_Q10CU3 & Glycosyl hydrolase family 3, Oryza sativa & 43916 & 8.20 & $x$ & & $x$ & & & \\
\hline UniRef90_Q10M79 & Alpha $L$ arabinofuranosidase, Oryza sativa & 73965 & 4.73 & & & & & $x$ & \\
\hline UniRef90_Q10NX8 & Beta galactosidase 6, Oryza sativa & 92780 & 5.52 & $x$ & & & $x$ & & \\
\hline UniRef90_Q2R3E0 & Glycosyl hydrolases family 38, Oryza sativa & 114085 & 5.85 & & $x$ & & & & $x$ \\
\hline UniRef90_Q2RAZ2 & Alpha $L$ arabinofuranosidase, Oryza sativa & 73421 & 4.57 & $x$ & & $x$ & $x$ & $x$ & $x$ \\
\hline UniRef90_Q43417 & Peroxidase, Cenchrus ciliaris & 32473 & 7.50 & & & & & $x$ & \\
\hline UniRef90_Q53MP2 & Beta D-xylosidase, Oryza sativa & 82557 & 6.62 & & $x$ & & & & \\
\hline UniRef90_Q5CCP6 & Beta galactosidase, Pyrus pyrifolia & 94782 & 8.12 & & $x$ & & & & \\
\hline UniRef90_Q513F3 & Peroxidase 5 , Triticum monococcum & 27533 & 5.72 & & $x$ & & & & \\
\hline UniRef90_Q6L619 & Beta galactosidase, Raphanus sativus & 92580 & 8.36 & $x$ & & & & $x$ & \\
\hline UniRef90_Q7G3T8 & Beta galactosidase 13 , Oryza sativa & 91940 & 6.06 & & $x$ & & & & \\
\hline UniRef90_Q8GUY1 & Pectinesterase, Lolium perenne & 24837 & 7.81 & & $x$ & & & & \\
\hline UniRef90_Q8RUV9 & Beta galactosidase 1, Oryza sativa & 91652 & 5.71 & & $x$ & & & & \\
\hline UniRef90_Q9FXT4 & Alpha galactosidase, Oryza sativa & 45792 & 7.91 & & & & & $x$ & $x$ \\
\hline UniRef90_Q9LLB8 & Exoglucanase, Zea mays & 66900 & 6.99 & $x$ & $x$ & $x$ & $x$ & & $x$ \\
\hline UniRef90_Q9XE93 & Exhydrolase II, Zea mays & 68330 & 6.16 & $x$ & $x$ & $x$ & $x$ & $x$ & $x$ \\
\hline UniRef90_Q9XEl3 & Beta D-glucan exohydrolase isoenzyme, Hordeum vulgare & 67862 & 6.24 & $x$ & $x$ & & $x$ & & \\
\hline \multicolumn{10}{|l|}{ Disease and defence } \\
\hline UniRef100_P25272 & Kunitz-type trypsin inhibitor 1, Glycine max & 22531 & 4.77 & $x$ & & & & & \\
\hline UniRef90_A7IZL3 & Invertase inhibitor, Coffea canephora & 20205 & 6.68 & & $x$ & & & & \\
\hline UniRef90_B6TA80 & Thaumatin-like protein, Zea mays & 17632 & 6.75 & & & & & $x$ & \\
\hline UniRef90_B6TDW7 & Secretory protein, Zea mays & 24467 & 4.64 & & & & & $x$ & \\
\hline UniRef90_B6TT00 & Endochitinase PR4, Zea maize & 28545 & 4.96 & $x$ & & & & $x$ & \\
\hline UniRef90_B6TTY1 & Germin-like protein, Zea maize & 26764 & 7.25 & $x$ & & $x$ & & $x$ & $x$ \\
\hline UniRef90_B6TWH6 & Lysosomal Pro $\times$ carboxypeptidase, Zea mays & 59936 & 5.62 & $x$ & $x$ & $x$ & $x$ & & $x$ \\
\hline
\end{tabular}


Table 1 Identification of proteins assigned to the apoplast. (Continued)

\begin{tabular}{|c|c|c|c|c|c|c|c|c|c|}
\hline UniRef90_B6UB57 & Lysosomal protective protein, Zea maize & 53540 & 5.87 & $x$ & $x$ & $x$ & & $x$ & $\mathrm{x}$ \\
\hline UniRef90_O24007 & Chitinase, Oryza sativa & 18956 & 4.83 & $x$ & & $x$ & $x$ & $x$ & $x$ \\
\hline UniRef90_P01063 & Bowman-Birk-type proteinase inhibitor C II, Glycine max & 9194 & 4.38 & $x$ & & & & & \\
\hline UniRef90_P29022 & Endochitinase A, Zea maize & 29105 & 7.85 & & & & & $x$ & \\
\hline UniRef90_Q5U1S9 & Class III peroxidase 14 , Oryza sativa & 37174 & 5.77 & & & & & $x$ & \\
\hline UniRef90_Q6EUS1 & Class III peroxidase 27 , Oryza sativa & 33300 & 8.09 & & $x$ & & & & $x$ \\
\hline UniRef90_Q6TM44 & Germin-like protein, Zea mays & 21873 & 6.04 & $x$ & $x$ & $x$ & $x$ & $x$ & $x$ \\
\hline UniRef90_Q7M1R1 & Chitinase, Gladiolus $\times$ gandavensis & 30695 & 5.77 & $x$ & & $x$ & $x$ & $x$ & $x$ \\
\hline \multicolumn{10}{|c|}{ Protein destination and storage } \\
\hline UniRef90_B6TG95 & Vignain, Zea mays & 38823 & 4.68 & $x$ & $x$ & $x$ & $x$ & $x$ & $x$ \\
\hline UniRef90_B6TYX7 & Polygalacturonase inhibitor 1 , Zea mays & 30011 & 8.08 & & $x$ & & & $x$ & $x$ \\
\hline \multicolumn{10}{|c|}{$\underline{\text { Secondary metabolism }}$} \\
\hline UniRef90_O64411 & Polyamine oxidase, Zea mays & 56308 & 5.63 & & $x$ & & & & \\
\hline \multicolumn{10}{|l|}{$\underline{\text { Signal transduction }}$} \\
\hline UniRef90_B6TWC3 & Rhicadhesin receptor, Zea mays & 23726 & 9.20 & & $x$ & $x$ & & & \\
\hline UniRef90_B9MZ47 & Fasciclin-like AGP 144 protein, Populus trichocarpa & 24786 & 8.63 & & & & & $x$ & \\
\hline \multicolumn{10}{|l|}{ Transporters } \\
\hline UniRef90_B4FB54 & Non-specific lipid transfer protein, Zea mays & 12084 & 9.60 & & $x$ & & & & \\
\hline UniRef90_B6SP11 & Non-specific lipid transfer protein, Zea mays & 9802 & 8.73 & & $x$ & & & & \\
\hline UniRef90_B6SY96 & Non-specific lipid transfer protein, Zea mays & 12011 & 9.29 & & $x$ & & & & \\
\hline UniRef90_B6TRB2 & Copper ion binding protein, Zea maize & 17057 & 9.78 & & & $x$ & & & \\
\hline UniRef90_P05046 & Lectin, Glycine max & 30908 & 5.60 & $x$ & & & $x$ & & \\
\hline UniRef90_P19656 & Non-specific lipid transfer protein, Zea mays & 11697 & 8.74 & & $x$ & & & & $x$ \\
\hline UniRef90_Q04672 & Sucrose-binding protein, Glycine max & 60484 & 6.42 & $x$ & & & & & \\
\hline
\end{tabular}

UniProt database identifiers, along with molecular weight $(\mathrm{mW})$ and isoelectric point $(\mathrm{pl})$ are shown. The identification of the respective proteins using different extraction solutions is indicated (i: water, ii: $100 \mathrm{mM}$ sodium phosphate buffer, iii: $25 \mathrm{mM}$ Tris-HCl, iv: $100 \mathrm{mM}$ sorbitol, v: $20 \mathrm{mM}$ ascorbic acid/20 mM CaCl , vi: $50 \mathrm{mM} \mathrm{NaCl})$.

$0.01 \mu \mathrm{M}\left(\mathrm{NH}_{4}\right)_{6} \mathrm{Mo}_{7} \mathrm{O}_{24}, 200 \mu \mathrm{M}$ Fe-EDTA. Nutrient solution was changed twice a week to avoid nutrient deficiencies. The experiments were carried out under greenhouse conditions with an average day/night temperature of $28 / 18^{\circ} \mathrm{C}$ and a photoperiod of $14 \mathrm{~h}$ for 5 weeks with relative humidity about $70 \% \pm 5 \%$. The fifth and sixth leaf from medium part of the stem was harvested $16 \mathrm{~d}$ after reaching the full nutrient solution for collection of apoplast proteins.

\section{Extraction of apoplastic and symplastic proteins}

Apoplastic proteins were collected using the infiltrationcentrifugation technique [43] with minor modifications. Leaves were cut into segments of about $5.5 \mathrm{~cm}$ and washed with deionised water. For infiltration, leaf segments were placed in plastic syringes $(60 \mathrm{ml})$ filled with $40 \mathrm{ml}$ of the respective infiltrating medium and were infiltrated by pulling the plunger, producing a reduced pressure of estimated about $20 \mathrm{kPa}$. Leaves were infiltrated either with water, $20 \mathrm{mM}$ ascorbic acid/20 mM $\mathrm{CaCl}_{2}, 100 \mathrm{mM}$ sorbitol, $0.1 \mathrm{M}$ sodium phosphate buffer (pH 6.5), $25 \mathrm{mM}$ Tris- $\mathrm{HCl}$ (pH 8.0) or $50 \mathrm{mM} \mathrm{NaCl}$ (Figure 1). Thereafter, intact leave segments were carefully blotted dry, and then placed in a $10 \mathrm{ml}$ plastic vessel and centrifuged immediately at $400 \mathrm{~g}$ for $5 \mathrm{~min}$ at $5^{\circ}$
C. The clear infiltrate, now referred to as apoplast fraction, was collected at the bottom of the tube.

After the extraction of the apoplastic fraction, the residual leaf tissue was shock frozen in liquid nitrogen, thawed, and centrifuged at $715 g$ for 5 min for cell sap extraction, now referred to as symplast fraction. Four pools of extracts from five plants each were combined for subsequent analyses. Extracts were stored at $-80^{\circ} \mathrm{C}$ until analysis.

\section{Gel electrophoretic protein separation}

Proteins contained in the different extracts were precipitated by chloroform/methanol method [44]: $200 \mu \mathrm{l}$ of sample was mixed with $800 \mu \mathrm{l} \mathrm{MeOH}, 400 \mu \mathrm{l}$ chloroform and $600 \mu$ deionized water. The incubation at $4{ }^{\circ} \mathrm{C}$ for $5 \mathrm{~min}$ was followed by a centrifugation step $(9,000 \mathrm{~g}$, $2 \mathrm{~min}, 4^{\circ} \mathrm{C}$ ). The upper phase was removed and $600 \mu \mathrm{l}$ $\mathrm{MeOH}$ was added to the lower and interphase. A further centrifugation sedimented the proteins, the supernatant was removed and the pellet was dried in a vacuum centrifuge.

For one-dimensional separation of proteins, the pellets were dissolved in $10 \%$ glycerol, $2.3 \%$ SDS, $5 \% \beta$-mercaptoethanol, $0.25 \%$ bromphenol blue, $63 \mathrm{mM}$ Tris- $\mathrm{HCl}$ (pH 6.8). The 2-D Quant Kit (GE Healthcare, http:// 
www.gehealthcare.com) was used for determining the protein concentration. A sample of $10 \mu \mathrm{g}$ was separated by SDS-PAGE according to Laemmli [45]. The twodimensional separation of proteins was accomplished as described in Zörb et al. [46] with the following modifications. Protein pellets were first dissolved in $8 \mathrm{M}$ urea, $2 \mathrm{M}$ thiourea, $0.5 \%$ IPG (immobilized $\mathrm{pH}$ gradient) buffer, $4 \% \mathrm{w} / \mathrm{v}$ CHAPS, $30 \mathrm{mM} \mathrm{DTT}, 20 \mathrm{mM}$ Tris and then dialyzed using $3.5 \mathrm{kDa}$ cut-off membrane (ZelluTrans, Carl Roth, http://www.carlroth.com) against the same buffer. The protein concentration was determined with the 2-D Quant Kit (GE Healthcare) and $25 \mu \mathrm{g}$ of protein were separated on IPG strips of $7 \mathrm{~cm}$ in length with $\mathrm{pH}$ gradient of 3-10. Protein gels were stained according to the hot-staining protocol with Coomassie R350 tablets (PlusOne Coomassie tablets PhastGel Blue R-350, GE Healthcare) [47] and digitized with an Epson Perfection V700 Photo scanner (Epson, http://www. epson.com).

\section{LC-MS-based protein identification}

Dialyzed protein extracts were precipitated by chloroform/methanol method and about $30 \mu \mathrm{g}$ of protein were resolubilized in $50 \mu \mathrm{l} 0.1 \%$ Rapigest (Waters Corporation, http://www.waters.com) in $50 \mathrm{mM}$ ammonium bicarbonate. Protein concentrations were determined using the Bradford method [48] and bovine serum albumin as standard protein. Five $\mu \mathrm{g}$ of protein were reduced, alkylated and digested with trypsin over night at $37^{\circ} \mathrm{C}$ as described earlier [49]. The enzymatic reaction was stopped with $1 \mathrm{~N} \mathrm{HCl}$ and peptide solutions were adjusted to $0.1 \mu \mathrm{g} / \mu \mathrm{l}$ final concentration.

Three $\mu \mathrm{l}$ of protein digest were used for LC-separation on a nanoAcquity UPLC system (Waters) followed by mass spectrometry analysis on a Q-TOF Premier MS instrument (Waters) in a data directed analysis (DDA) mode, as described in Agrawal et al. [50].

Peptide separation was performed on a $180 \mu \mathrm{m} \times 20$ mm Symmetry $(5 \mu \mathrm{m}) \mathrm{C} 18$ precolumn (Waters) coupled to a $150 \mathrm{~mm} \times 75 \mu \mathrm{m} \mathrm{BEH130}(1.7 \mu \mathrm{m}) \mathrm{C} 18$ column (Waters), with a gradient of $3-40 \%$ actonitrile over 90 min. The MS operated in a positive ion mode with a source temperature of $80^{\circ} \mathrm{C}$, a cone gas flow of $50 \mathrm{l} / \mathrm{h}$, and a capillary voltage of approximately $3 \mathrm{kV}$. Mass spectra were acquired in a continuum $\mathrm{V}$-mode and spectra integrated over $1 \mathrm{~s}$ intervals using MassLynx 4.1 software (Waters). The instrument was calibrated using selected fragment ions of the CID (collision-induced dissociation) of Glu-Fibrinopeptide B (SIGMA-ALDRICH, http://www.sigmaaldrich.com). Automatic data directed analysis (DDA) was employed for MS/MS analysis on doubly and triply charged precursor ions. The MS spectra were collected from $\mathrm{m} / z 400$ to $\mathrm{m} / z 1600$, and product ion MS/MS spectra were collected from $m / z 50$ to $m / z 1600$. Lock mass correction of the precursor and product ions was conducted with $500 \mathrm{fmol} / \mu \mathrm{l} \mathrm{Glu-Fibri-}$ nopeptide B in $0.1 \%$ formic acid in AcN/water (50:50, v/ v) respectively, and introduced via the reference sprayer of the NanoLockSpray interface. ProteinLynx GlobalSERVER v2.3 software was used as a software platform for data processing, deconvolution, de novo sequence annotation of the spectra, and database search. A 10 ppm peptide, $0.1 \mathrm{Da}$ fragment tolerance, one missed cleavage, and variable oxidation (Met) and carbamidomethylation (Cys) were used as the search parameters.

The resulting mass spectra were searched against the protein index of the UniProt viridiplantae database (release: July 2010 with 722.718 protein sequences) for protein identification applying the algorithm implemented in the ProteinLynxGlobalServer software (PLGS, Waters Cooperation). All samples were run as technical triplicates. Protein identifications consistent in two out of three LC-MS runs were considered as present in that sample. The false discovery rate was set to $4 \%$ of proteins included in the database.

Hierarchical clustering of protein abundances was performed using Gene Expression Similarity Investigation Suite Genesis v1.7.6 [51]. Average linkage clustering was applied for LC-MS experiments and protein abundances.

\section{Additional material}

Additional file 1: Biological reproducibility of protein profiles from the maize leaf apoplast as resolved by 1-DE. Apoplastic proteins were extracted with water (i) or $100 \mathrm{mM}$ sodium phosphate buffer (ii). Two independent experiments were performed to assure consistent protein patterns.

Additional file 2: Identification of proteins from the apoplast of maize leaves. UniProt database identifiers, along with molecular weight $(\mathrm{mW})$ and isoelectric point (pl) are shown. The cellular localisation was assigned using Expasy tools Target P (http://www.cbs.dtu.dk/services/ TargetP/) and WoLF PSORT (http://wolfpsort.org/). The identification of the respective proteins using different extraction solutions is indicated (i: water, ii: 100 mM sodium phosphate buffer, iii: 25 mM Tris-HCl, iv: 100 mM sorbitol, v: $20 \mathrm{mM}$ ascorbic acid/20 mM CaCl , vi: $50 \mathrm{mM} \mathrm{NaCl}$ ).

Additional file 3: Identification of proteins from the apoplast of maize leaves. Provided are the UniProt database identifiers, the PLGS score, probability score for identification, number of identified peptides, protein coverage and the peptide sequence.

Additional file 4: Proteins identified in apoplast extracts of all six infiltration solutions.

Additional file 5: Example of protein identification from apoplastic extracts using nanoLC-ESI-Q-TOF MS. The database search against the protein index of UniProt led to the identification of exhydrolase II [Q9XE93]. The amino acid sequence of the corresponding protein is shown on top with the detected peptides underlined. The de novo sequence of a selected peptide with precursor mass $\mathrm{m} / \mathrm{z} 859.4698$ (charge 3 ) is shown. This peptide is marked in bold within the protein sequence. 


\section{Abbreviations}

LC-MS/MS: liquid chromatography tandem mass spectrometry; 1-DE: onedimensional gel electrophoresis; 2-DE: two-dimensional gel electrophoresis

\section{Acknowledgements}

We thank Stephanie thor Straten and Annegret Thießen for excellent technical assistance. MS acknowledges the award of a DAAD scholarship and KW the support by COST Action 'Plant Proteomics in Europe' (FA0603).

\section{Author details}

1 Institute of Plant Nutrition and Soil Science, Christian Albrechts University, Hermann-Rodewald-Strasse 2, 24118 Kiel, Germany. ${ }^{2}$ Leibniz Institute of Plant Genetics and Crop Plant Research, Corrensstrasse 3, 06466 Gatersleben, Germany. ${ }^{3}$ Leibniz Institute of Vegetable and Ornamental Crops, TheodorEchtermeyer-Weg 1, 14979 Großbeeren, Germany.

\section{Authors' contributions}

KW carried out protein extractions, protein separations, data evaluation and manuscript preparation. MS performed plant cultivation, apoplastic preparations and contributed to protein separations. AM conceived mass spectrometry analyses and contributed to manuscript writing. HPM participated in discussions during experimental work and manuscript preparation. KHM conceived the project and worked on manuscript preparation. All authors read and approved the final manuscript.

\section{Competing interests}

The authors declare that they have no competing interests.

Received: 1 November 2011 Accepted: 22 December 2011 Published: 22 December 2011

\section{References}

1. Sattelmacher B, Mühling KH, Pennewiss K: The apoplast - its significance for the nutrition of higher plants. Zeitschrift für Pflanzenernährung und Bodenkunde 1998, 161:485-498.

2. Hoson T: Apoplast as the site of response to environmental signals. $J$ Plant Res 1998, 111:167-177.

3. Dietz K-J: The extracellular matrix of the plant cell: Location of signal perception, transduction and response. In Prog Bot. Edited by: Esser K, Lüttge U, Kadereit J, Beyschlag W. Berlin Heidelberg New York: Springer; 2000:215-237.

4. Mühling $\mathrm{KH}$, Läuchli $\mathrm{A}$ : Interaction of $\mathrm{NaCl}$ and $\mathrm{Cd}$ stress on compartmentation pattern of cations, antioxidant enzymes and proteins in leaves of two wheat genotypes differing in salt tolerance. Plant Soil 2003, 253:219-231.

5. Dani V, Simon W, Duranti M, Croy R: Changes in the tobacco leaf apoplast proteome in response to salt stress. Proteomics 2005, 5:737-745.

6. Tasgin E, Atici O, Nalbantoglu B, Popova LP: Effects of salicylic acid and cold treatments on protein levels and on the activities of antioxidant enzymes in the apoplast of winter wheat leaves. Phytochemistry 2006, 67:710-715.

7. Ramanjulu S, Kaiser W, Dietz KJ: Salt and drought stress differentially affect the accumulation of extracellular proteins in barley. Zeitschrift Fur Naturforschung C-a Journal of Biosciences 1999, 54:337-347.

8. Wimmer MA, Mühling KH, Läuchli A, Brown PH, Goldbach HE: The interaction between salinity and boron toxicity affects the subcellular distribution of ions and proteins in wheat leaves. Plant Cell Environ 2003, 26:1267-1274.

9. Alves M, Francisco R, Martins I, Ricardo CPP: Analysis of Lupinus albus leaf apoplastic proteins in response to boron deficiency. Plant Soil 2006, 279:1-11.

10. Fecht-Christoffers MM, Braun HP, Lemaitre-Guillier C, VanDorsselaer A, Horst WJ: Effect of Manganese toxicity on the proteome of the leaf apoplast in cowpea. Plant Physiology 2003, 133:1935-1946.

11. Soares NC, Francisco R, Vielba JM, Ricardo CP, Jackson PA: Associating wound-related changes in the apoplast proteome of Medicago with early steps in the ROS signal-transduction pathway. J Proteome Res 2009, 8:2298-2309.

12. Bhushan D, Pandey A, Choudhary MK, Datta A, Chakraborty S, Chakraborty N: Comparative proteomics analysis of differentially expressed proteins in chickpea extracellular matrix during dehydration stress. Mol Cell Proteomics 2007, 6:1868-1884.

13. Pandey A, Rajamani U, Verma J, Subba P, Chakraborty N, Datta A, et al: Identification of Extracellular Matrix Proteins of Rice (Oryza sativa L.) Involved in Dehydration-Responsive Network: A Proteomic Approach. $J$ Proteome Res 2010, 9:3443-3464.

14. Floerl S, Druebert C, Majcherczyk A, Karlovsky P, Kues U, Polle A: Defence reactions in the apoplastic proteome of oilseed rape (Brassica napus var. napus) attenuate Verticillium longisporum growth but not disease symptoms. BMC Plant Biol 2008, 8:15.

15. Goulet C, Goulet MC, Michaud D: 2-DE proteome maps for the leaf apoplast of Nicotiana benthamiana. Proteomics 2010, 10:2536-2544.

16. Anand A, Lei ZT, Sumner LW, Mysore KS, Arakane Y, Bockus WW, et al: Apoplastic extracts from a transgenic wheat line exhibiting lesion-mimic phenotype have multiple pathogenesis-related proteins that are antifungal. Mol Plant-Microbe Interact 2004, 17:1306-1317.

17. Djordjevic MA, Oakes M, Li DX, Hwang CH, Hocart CH, Gresshoff PM: The Glycine max xylem sap and apoplast proteome. Journal of Proteome Research 2007, 6:3771-3779.

18. Alvarez S, Goodger JQD, Marsh EL, Chen S, Asirvatham VS, Schachtman DP: Characterization of the maize xylem sap proteome. J Proteome Res 2006, 5:963-972.

19. Maldonado AM, Echevarria-Zomeno S, Jean-Baptiste S, Hernandez M, JorrinNovo JV: Evaluation of three different protocols of protein extraction for Arabidopsis thaliana leaf proteome analysis by two-dimensional electrophoresis. Journal of Proteomics 2008, 71:461-472.

20. Rodrigues SP, Ventura JA, Zingali RB, Fernandes RMB: Evaluation of sample preparation methods for the analysis of papaya leaf proteins through 2wo-dimensional gel electrophoresis. Phytochem Anal 2009, 20:456-464.

21. da Silva MAO, Garcia JS, de Souza G, Eberlin MN, Gozzo FC, Arruda MAZ: Evaluation of sample preparation protocols for proteomic analysis of sunflower leaves. Talanta 2010, 80:1545-1551.

22. Xie CJ, Wang D, Yang XY: Protein extraction methods compatible with proteomic analysis for the cotton seedling. Crop Sci 2009, 49:395-402.

23. Zheng Q, Song J, Doncaster K, Rowland E, Byers DM: Qualitative and quantitative evaluation of protein extraction protocols for apple and strawberry fruit suitable for two-dimensional electrophoresis and mass spectrometry analysis. J Agric Food Chem 2007, 55:1663-1673.

24. Delaplace $P$, van der Wal F, Dierick JF, Cordewener JHG, Fauconnier ML, du Jardin $\mathrm{P}$, et al: Potato tuber proteomics: Comparison of two complementary extraction methods designed for 2-DE of acidic proteins. Proteomics 2006, 6:6494-6497.

25. Jellouli N, Ben Salem A, Ghorbel A, Ben Jouira H: Evaluation of protein extraction methods for Vitis vinifera leaf and root proteome analysis by two-dimensional electrophoresis. J Integr Plant Biol 2010, 52:933-940.

26. Negri AS, Prinsi B, Scienza A, Morgutti S, Cocucci M, Espen L: Analysis of grape berry cell wall proteome: A comparative evaluation of extraction methods. J Plant Physiol 2008, 165:1379-1389.

27. Wang XC, Shi MJ, Lu XL, Ma RF, Wu CG, Guo AP, et al: A method for protein extraction from different subcellular fractions of laticifer latex in Hevea brasiliensis compatible with 2-DE and MS. Proteome Science 2010, 8:10.

28. Yao Y, Yang YW, Liu JY: An efficient protein preparation for proteomic analysis of developing cotton fibers by 2-DE. Electrophoresis 2006, 27:4559-4569.

29. Carpentier SC, Witters E, Laukens K, Deckers P, Swennen R, Panis B: Preparation of protein extracts from recalcitrant plant tissues: An evaluation of different methods for two-dimensional gel electrophoresis analysis. Proteomics 2005, 5:2497-2507.

30. Fan PX, Wang XC, Kuang TY, Li YX: An efficient method for the extraction of chloroplast proteins compatible for 2-DE and MS analysis. Electrophoresis 2009, 30:3024-3033.

31. Borderies G, Jamet E, Lafitte C, Rossignol M, Jauneau A, Boudart G, et al: Proteomics of loosely bound cell wall proteins of Arabidopsis thaliana cell suspension cultures: A critical analysis. Electrophoresis 2003, 24:3421-3432

32. Boudart G, Jamet E, Rossignol M, Lafitte C, Borderies G, Jauneau A, et al: Cell wall proteins in apoplastic fluids of Arabidopsis thaliana rosettes: Identification by mass spectrometry and bioinformatics. Proteomics 2005, 5:212-221. 
33. Paetzold R: Subzelluläre Proteomanalyse von Maisblättern (Zea mays L.) unter besonderer Berücksichtigung der $\mathrm{NaCl}$ - und B-Toxizität. M.Sc. thesis, Institute of Plant Nutrition: Justus Liebig University Giessen; 2006.

34. Robertson D, Mitchell GP, Gilroy JS, Gerrish C, Bolwell GP, Slabas AR: Differential extraction and protein sequencing reveals major differences in patterns of primary cell wall proteins from plants. J Biol Chem 1997, 272:15841-15848.

35. Li ZC, MCClure JW, Hagerman AE: Soluble and bound apoplastic activity for peroxidase, beta-D-glucosidase, malate dehydrogenase, and nonspecific arylesterase, in barley (Hordeum vulgare L.) and oat (Avena sativa L.) primary leaves. Plant Physiology 1989, 90:185-190.

36. Chivasa S, Ndimba BK, Simon WJ, Robertson D, Yu XL, Knox JP, et al: Proteomic analysis of the Arabidopsis thaliana cell wall. Electrophoresis 2002, 23:1754-1765.

37. Irshad M, Canut $H$, Borderies $G$, Pont-Lezica $R$, Jamet E: A new picture of cell wall protein dynamics in elongating cells of Arabidopsis thaliana: Confirmed actors and newcomers. BMC Plant Biol 2008, 8.

38. Gokulakannan GG, Niehaus K: Characterization of the Medicago truncatula cell wall proteome in cell suspension culture upon elicitation and suppression of plant defense. J Plant Physiol 2010, 167:1533-1541.

39. Cleves AE: Protein transport: The nonclassical ins and outs. Curr Biol 1997, 7:R318-R320.

40. Slabas AR, Ndimba B, Simon WJ, Chivasa S: Proteomic analysis of the Arabidopsis cell wall reveals unexpected proteins with new cellular locations. Biochem Soc Trans 2004, 32:524-528.

41. Cosgrove DJ: Growth of the plant cell wall. Nat Rev Mol Cell Biol 2005, 6:850-861

42. Hammerschmidt R: The dynamic apoplast. Physiol Mol Plant Pathol 2010, 74:199-200.

43. Lohaus G, Pennewiss K, Sattelmacher B, Hussmann M, Mühling KH: Is the infiltration-centrifugation technique appropriate for the isolation of apoplastic fluid? A critical evaluation with different plant species. Physiol Plant 2001, 111:457-465.

44. Wessel D, Flugge UI: A method for the quantitative recovery of protein in dilute-solution in the presence of detergents and lipids. Anal Biochem 1984, 138:141-143.

45. Laemmli UK: Cleavage of structural proteins during assembly of head of bacteriophage T4. Nature 1970, 227:680-685.

46. Zörb C, Schmitt S, Neeb A, Karl S, Linder M, Schubert S: The biochemical reaction of maize (Zea mays L.) to salt stress is characterized by a mitigation of symptoms and not by a specific adaptation. Plant Science 2004, 167:91-100.

47. Westermeier R, Naven T: Proteomics in Practice: A Laboratory Manual of Proteome Analysis. Weinheim, Germany: Wiley-VCH; 2002.

48. Bradford M: A rapid and sensitive method for the quantitation of microgram quantities of protein utilizing the principle of protein-dye binding. Anal Biochem 1976, 7:248-254.

49. Kaspar S, Matros A, Mock HP: Proteome and flavonoid analysis reveals distinct responses of epidermal tissue and whole leaves upon UV-B radiation of barley (Hordeum vulgare L.) seedlings. J Proteome Res 2010, 9:2402-2411.

50. Agarwal R, Matros A, Melzer M, Mock HP, Sainis JK: Heterogeneity in thylakoid membrane proteome of Synechocystis 6803. Journal of Proteomics 2010, 73:976-991.

51. Sturn A, Quackenbush J, Trajanoski Z: Genesis: cluster analysis of microarray data. Bioinformatics 2002, 18:207-208.

doi:10.1186/1746-4811-7-48

Cite this article as: Witzel et al: Comparative evaluation of extraction methods for apoplastic proteins from maize leaves. Plant Methods 2011 $7: 48$

\section{Submit your next manuscript to BioMed Central and take full advantage of:}

- Convenient online submission

- Thorough peer review

- No space constraints or color figure charges

- Immediate publication on acceptance

- Inclusion in PubMed, CAS, Scopus and Google Scholar

- Research which is freely available for redistribution

Submit your manuscript at www.biomedcentral.com/submit
Ciomed Central 